\section{A new black mildew fungus Meliola erumeliensis from Idukki, Kerala, India}

\section{V.B. Hosagoudar ${ }^{1}$, G.R. Archana ${ }^{2}$, M. Rajendraprasad ${ }^{2} \&$ A. Nazarudeen ${ }^{2}$}

1,2 Tropical Botanic Garden and Research Institute, Palode, Thiruvananthapuram, Kerala 695562, India

E-mail: vbhosagoudar@ rediffmail.com

During a survey of meliolaceous fungi in Idukki District of Kerala State, authors came across the plant, Drypetes elata, infected with a black mildew fungus. Microscopic examination of the fungus revealed the presence of a new species of the genus Meliola which is described here.

\section{Meliola erumeliensis sp. nov.}

(Fig. 1)

Coloniae hypophyllae, subdensae, ad $2 \mathrm{~mm}$ diam., confluentes. Hyphae rectae vel subrectae, opposite vel irregulariter acuteque vel laxe ramosae, laxe vel arte reticulatae, cellulae 11-32 x 6-8 $\mu \mathrm{m}$. Appressoria plerumque opposita, alternata, recta vel curvula, antrorsa, subantrorsa vel retrorsa, 9-22 $\mu \mathrm{m}$ longa; cellulae basilares cylindraceae vel cuneatae, $2-8 \mu \mathrm{m}$ longae; cellulae apicales ovatae, oblongae, integrae vel plerumque angularis, 8-16 x 8-11 $1 \mu \mathrm{m}$. Phialides appressoriis mixtus, numerosae, oppositae vel alternatae,

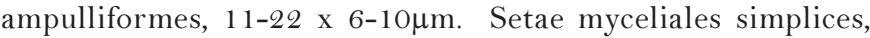
anfractuae, uncinatae, ad apicem obtusae, ad $294 \mu \mathrm{m}$ longae Perithecia globosa, dispersa vel aggregata, ad $176 \mu \mathrm{m}$ diam.; ascosporae obovoideae, 4-septatae, constrictae ad septatae, 36$43 \times 17-21 \mu \mathrm{m}$.

Colonies hypophyllous, subdense, up to $2 \mathrm{~mm}$ in diameter, confluent. Hyphae straight to substraight, branching opposite to irregular at acute to wide angles, loosely to closely reticulate,

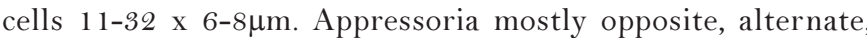
straight to curved, antrorse, subantrorse to retrorse, $9-22 \mu \mathrm{m}$ long; stalk cells cylindrical to cuneate, $2-8 \mu \mathrm{m}$ long; head cells

Date of online publication 26 June 2009

ISSN $0974-7907$ (online) | 0974-7893 (print)

Editor: Richard K. Mibey

\section{Manuscript details:}

Ms \# 02064

Received 13 September 2008

Finally accepted 20 May 2009

Citation: Hosagoudar, V.B., G.R. Archana, M. Rajendraprasad \& A. Nazarudeen (2009). A new black mildew fungus Meliola erumeliensis from Idukki, Kerala, India. Journal of Threatened Taxa 1(6): 347.

Copyright: (C) V.B. Hosagoudar, G.R. Archana, M. Rajendraprasad \& A Nazarudeen 2009. Creative Commons Attribution 3.0 Unported License. JoTT allows unrestricted use of this article in any medium for non-profit purposes, reproduction and distribution by providing adequate credit to the authors and the source of publication.

Acknowledgements: We thank Director, TBGRI, Palode for facilities. We are grateful to the Ministry of Environment \& Forests, New Delhi for the financial support and to the Forest Department, Govt. of Kerala for permission. ovate, oblong, entire to predominantly angular, 8-16 x 8-11 $\mu \mathrm{m}$. Phialides mixed with appressoria, numerous, opposite to alternate, ampulliform, 11-22 x 6-10 $\mu \mathrm{m}$. Mycelial setae simple, crooked, uncinate, obtuse at the tip, up to $294 \mu \mathrm{m}$ long. Perithecia globose, scattered to grouped, up to $176 \mu \mathrm{m}$ in diameter; ascospores obovoidal, 4septate, constricted at the septa, 36- $43 \times 17-21 \mu \mathrm{m}$.

\section{Material examined}

Type: 16.iii.2006, on the leaves of Drypetes elata (Bedd.) Pax \& Hoffm. (Euphorbiaceae), Murinjapuzha, Erumeli range, Peeramed, Idukki, Kerala, India, coll. A. Nazaruddin \& M.

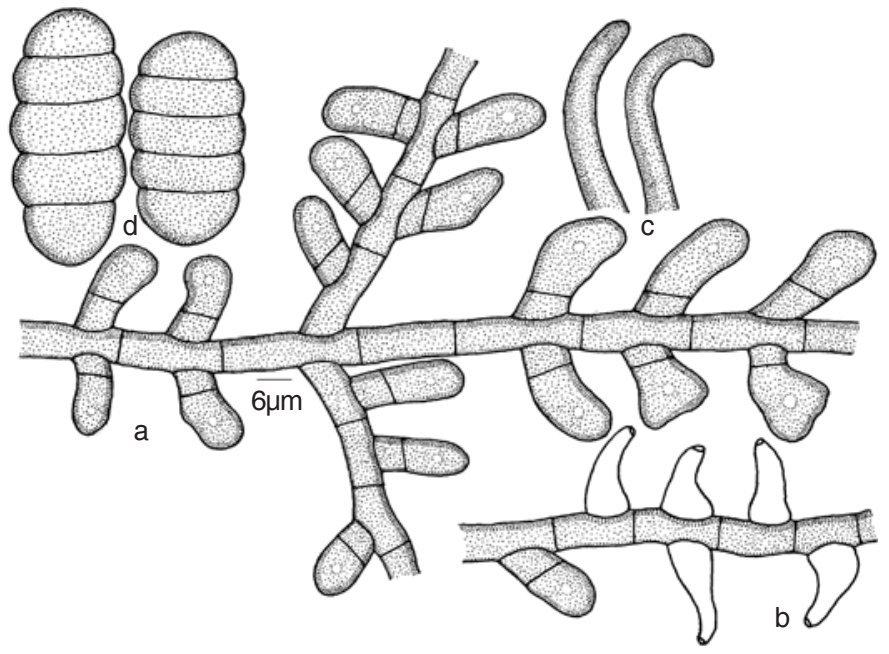

Figure 1. Meliola erumeliensis sp. nov. a - Appressorium; b - Phialide; c - Apical portion of the mycelial setae; d - Ascospores

Rajendraprasad HCIO 46831 (type), TBGT 2172 (isotype), (MycoBank \# MB 513424)

Meliola drypeticola Hosag. is the only species known on the host genera Drypetes and Epiprinus from the Western Ghats region of Peninsular India (Hosagoudar 1996). Meliola erumeliensis distinctly differs from it in having crooked and uncinate mycelial setae.

The species is named after the collection locality.

\section{References}

Hosagoudar, V.B. (1996). Meliolales of India. BSI, Calcutta, 363pp.

\section{OPEN ACCESS | FREE DOWNLOAD}

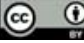

